\title{
Geo park Area Of Tourism Products and Information Center in Kintamani, Bali
}

\author{
I Gede Danan Segara Yasa R ${ }^{1}$, Ciptadi Trimarianto ${ }^{2}$, I Wayan Kastawan ${ }^{3}$ \\ Program Study of Architecture, Faculty of Engineering, Udayana University \\ Faculty of Engineering, Udayana University \\ Denpasar, Bali \\ Segaradanan@yahoo.co.id \\ Program Study of Architecture, Faculty of Engineering, Udayana University \\ Faculty of Engineering, Udayana University \\ Denpasar, Bali \\ Program Study of Architecture, Faculty of Engineering, Udayana University \\ Faculty of Engineering, Udayana University \\ Denpasar, Bali
}

\begin{abstract}
Tourism Information Center and Product Showcase is a place that functions to promote, inform and sell tourism products in Kintamani.The function of this place is to inform the tourists who visit Batur Geopark so they can be more familiar with tourism products, which are divided into tourism products and goods products. Tourism products accommodated in this place are tourism object, tourism attraction, and service products, while for goods product accommodated are culinary products, handicrafts, and souvenirs. There are three important elements in designing: function, structure and aesthetic. From these elements, the aesthetic element is an element that distinguishes architecture from other design science. In order to achieve aesthetic element, there are 6 principles: (1) Unity, (2) Balance, (3) Proportion, (4) Scale, (5) Rhythm, and (6) Emphasis. In designing Information Center and Tourism Product Showcase of Batur Geopark in Kintamani the principles mentioned are applied to the building façade elements.
\end{abstract}

\section{Index Terms — information center and tourism product showcase, facade, aestheticsu}

\section{INTRODUCTION}

To support tourism activities in Kintamani, a forum is needed to promote and sell tourism products offered to foreign tourists and local tourists. The tourism products in question are tourist objects, tourist attractions, transportation services and goods products that facilitate tourists in their tourism activities. In addition to products in the form of services, products in the form of gifts or souvenirs from Batur Geopark are also needed to give mementos to visitors and become a characteristic of this region. However, in this area there is no place to promote tourism products and goods, especially agricultural processed products, which are mostly unprocessed raw products so that the selling value tends to be low so that tourists are less interested in these raw products. Thus, the Information Center and Showcase for Tourism Products in the Batur Geopark Area in Kintamani was designed as a forum to accommodate these goals. In designing the Information Center and Showcase for Tourism Products in the Batur Geopark Area in Kintamani, there are 3 main elements in designing, namely structure,

function and aesthetics. The aesthetic element is an element that distinguishes architecture from other design sciences, by achieving aesthetics, the building will have an attractive, pleasing to the eye and give a special impression to the building. To achieve aesthetics, there are 6 design principles which are divided into Unity, Balance, Proportion, Scale, Rhythm, and Emphasis.

\section{APPLICATION OF ESTHETIC PRINCIPLES}

\section{A. Basic Reference}

According to [1] aesthetics is a theory of perception in a very broad sense and includes all types of perceptions of 
pleasure and suffering so that it emphasizes the subject more in enjoying art, from this understanding it can be concluded that aesthetics is more abstract because it depends on the judgment of each person. which tends to differ based on the level of sensitivity and knowledge. Because it is abstract, it requires pu-la sensitivity and intelligence to achieve aesthetics. There are several principles that can be used in an effort to achieve aesthetics. According to (Irawan, 2013) these principles include: (1) unity (Unity), (2) Balance, (3) Proportion, (4) Scale, (5) Rhythm ( Rhythm), and (6) Emphasis (1) unity is the principle of proportion, balance, rhythm applied creatively to produce a successful and enjoyable visual effect. If one of the pioneers, balance and rhythm are not achieved, unity will also not be achieved so it is very important for a designer to understand this principle. (2) Balance is when each element in a design looks the same weight and does not intimidate other parts. The balance is divided into 3 , namely symmetrical balance, which means that each part has the same size and shape, asymmetrical balance, that is, each element has a different shape but still appears to have the same weight and does not dominate one another and radial balance, namely balance which is generally circular and spreads from a central point (3) Proportion is the relationship between a part of an object and the whole object. (4) Scale is a good comparison between buildings and humans, there are three types of scales used depending on the function of the building, namely the intimate scale, the normal scale and the monu-mental / grand scale. The intimate scale is usually used for places that require an intimate atmosphere and close human relations such as cafes and rooms, while the monumental scale is usually used for places where humans look small and give a feeling of fear / awe such as sacred buildings, country palaces and buildings. other great. (5) Rhythm or rhythm is the regular motion of visual elements having proportional and measured intervals. Rhythm is divided into repetition, alternating, progression (from small to large or from short to long) and regression (from large to small or from long to short) (6) Emphasis is the most prominent focal point or draws attention to a composition design, this can be achieved by placing in the center of balance, differentiating size, shape, color or texture. If the principles above can be understood and achieved by a designer, the design will have a good aesthetic value. Figure 1. An example of the application of several aesthetic elements to objects and buildings.
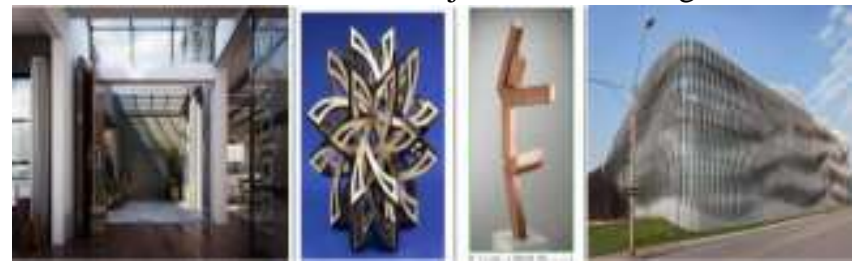

Fig. 1. Unity (Left) Achieved Due To The Harmony Of The Color Of Each Component, Examples Of Balance (Radial, Asymmetrical And Symmetrical) And Rhythm That Are Formed From The Facade Of The Building

\section{B. Balance, Emphasis and Unity}

In the building display of the Information Center and Showcase of Tourism Products for the Batur Geopark Area in Kin-tamani, a symmetrical balance can be seen between the left and right sides of the building if divided by a line in the middle. Due to this balance, there is no part of the building that sticks out to interfere with vision and closes off other buildings. The drawback of this symmetrical balance is that the building with a touch of wooden nuances on the ceiling makes the atmosphere of the space more modern, combined with yellow lighting that makes the atmosphere feel warm. which looks stiff and boring so that to reduce the boring impression that arises due to the symmetrical balance of the building, the elements on the left and right sides of the building are made differently, brick elements on the right of the building and more wood elements on the left side of the building. Emphasis in this building is placed in the center of balance so that it attracts the attention of visitors, besides to add a special impression the type and color of the material is distinguished by the color of the surrounding material. Symmetrical balance in the design of the Information Center and Showcase for Tourism Products in the Batur Geopark Area in Kin-tamani is an important element to achieve the principle of unity. Apart from this symmetrical balance, the use of all doff colored materials and local materials that match the Harmony With Nature theme helps the building to achieve unity in each element and unity with the surrounding environment. Figure 2.is a picture of balance, Emphasis and unity in the achieved building.

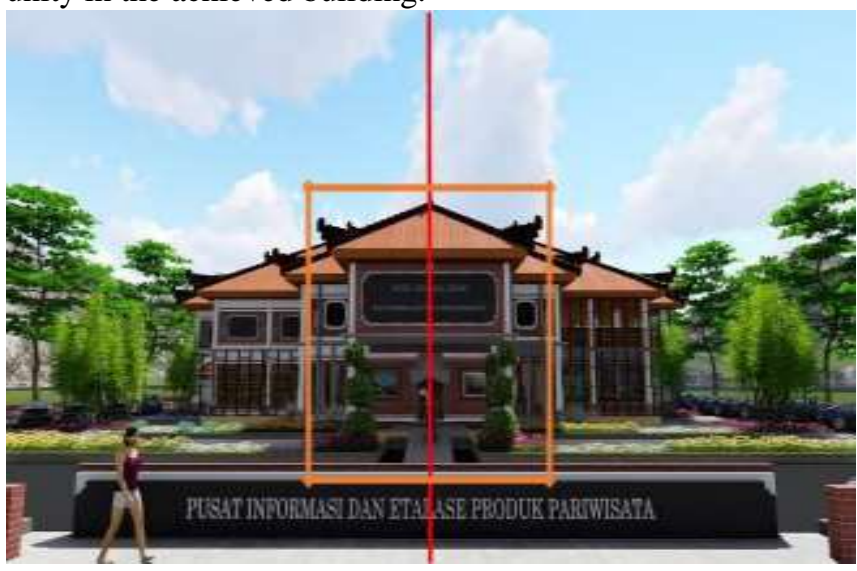

Fig. 2. Balance, Emphasis and Unity in the Information Center Building and Showcase for Tourism Products in the Batur Geopark Area in Kintamani, Bali.

\section{Scale and Proportion}

Overall, there are 2 types of scales used in this building, namely the normal scale and the intimate scale. The normal scale is used in the information center and product storefront function because it does not require a special atmosphere created by the intimate scale or the monumental scale, while the intimate scale is used in the cafe area so that the atmosphere in the cafe becomes more intimate and creates warmth and closeness for visitors. 
The proportions of each part of the building do not seem to dominate each other so that it helps to achieve unity in the building such as the proportion of the column to the entire building which is not too large so that it does not make the building look monumental. In Figure 3, we can see the normal scale use of the information center and cafe functions.

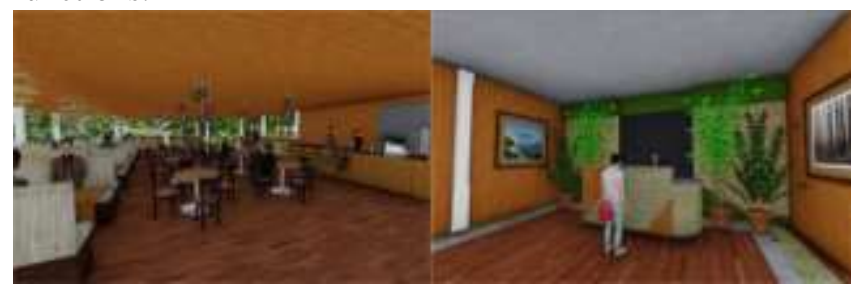

Fig. 3. Use of Intimate Scale in Cafes (Left) and Use of Normal Scale at Information Centers (Right).

From Figure 3, it can be seen that the ceiling at the information center is made taller and white in color so that it looks wider and does not seem to be pressing on the humans inside. Whereas in the cafe the ceiling is made slightly lower with a dark color so that the visitors feel even more depressed and narrow so that the atmosphere of the cafe is warmer and closer.

\section{Rhythm}

Repetition of several elements in the building such as repetition of columns with the same shape and color as well as repetition of sun shading from wood and repetition of vegetation such as trees and ornamental plants. The repetition of sun shading is made vertical and made dynamic so that it is not boring to look at and also reduces boredom due to large glass elements, while the repetition of ornamental plants in the front part makes the impression of taking visitors to the building entrance. Figure 3 below is an example of the rhythm produced by vegetation and sun shading towards the building entrance.

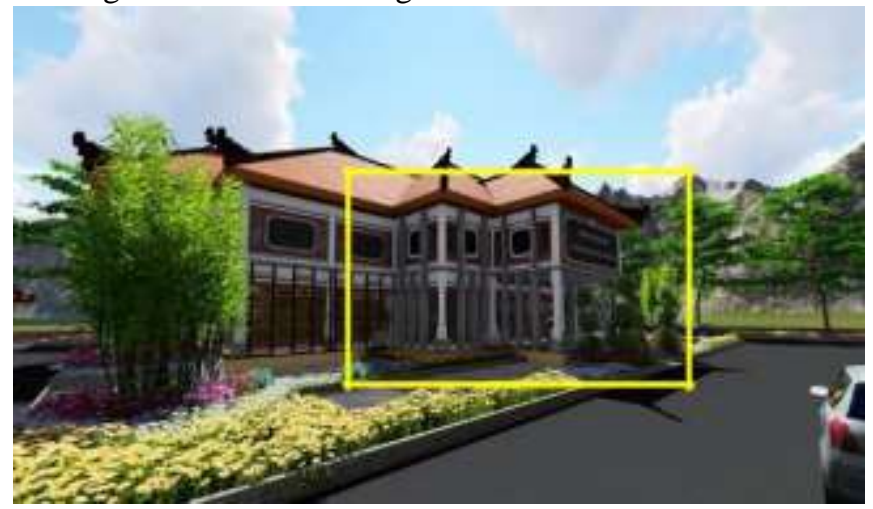

Fig. 3. Use of Intimate Scale in Cafes (Left) and Use of Normal Scale at Information Centers (Right).

\section{CONCLUSION}

By using the principles of (1) Unity, (2) Balance, (3) Proportion, (4) Scale, (5) Rhythm and (6) Emphasis which is applied to the form of buildings, facades and other elements, it is hoped that the design of the Information
Center and Showcase for Tourism Products in the Batur Geopark Area in Kintamani can achieve aesthetics so that the three elements in architecture can be fulfilled. The achievement of aesthetic elements in this design makes the building have more value in terms of visuals so that it is expected to be more inviting for tourists as the main purpose of this function.

\section{REFERENCES}

[1] D.K Ching, Francis. 2007. Architecture: Form, Space and Order. John Willey and Son, New Jersey.

[2] Irawan, Bambang. 2013. Dasar-Dasar Desain: Untuk Arsitektur, Interior Arsitektur, Seni Rupa, Desain Produk Industri dan Desain Komunikasi Visual. Griya Kreasi (Penebar Swadaya Group), Depok

[3] Levinson, Jerrold. 2005. The Oxford Handbook of Aesthetics. Oxford University Press, New York.

[4] Segara, Gede Danan Segara. 2017. Pusat Informasi dan Etalase Produk Pariwisata Kawasan Batur Ge-opark di Kintamani. UNUD, Bali.

[5] Sheppard, Anne. 2009. Aesthetics: An Introduction To The Philosophy Of Art. Oxford University Press, New York.

[6] Sutrisno, Mudji. 2005. Teks-Teks Kunci Estetika: Filsafat Seni, Galangpress (Anggota IKAPI), Yogyakarta. 